\title{
Distinctive REE patterns for tholeiitic and calc-alkaline magma series co-occurring at Adatara volcano, Northeast Japan
}

\author{
Akihiko Fujinawa \\ Department of Earth Sciences, Ibaraki University, Bunkyo 2-1-1, Mito 310, Japan
}

(Received July 12, 1991; Accepted February 26, 1992)

\begin{abstract}
Rare earth element (REE) concentrations were precisely determined by inductively coupled argon plasma/atomic emission spectrometry (ICP) for 9 tholeiitic and 13 associated calc-alkaline rocks from Adatara volcano, located at the volcanic front of Northeast Japan arc. The tholeitic samples commonly display nearly flat REE patterns, whereas the calc-alkaline samples characteristically show concave light REE-enriched patterns. In both suites, the REEs, with the exception of Eu, are positively correlated to varying extents with $\mathrm{K}_{2} \mathrm{O}$ and other incompatible elements. Eu concentrations in the calc-alkaline suite do not vary significantly, resulting in significant negative Eu anomalies. In the tholeiitic suite, chondritenormalized $(\mathrm{Ce} / \mathrm{Yb})_{\mathrm{CN}}$ ratios are low and show little variation (1.54-1.80) over a significant range in $\mathrm{SiO}_{2}$ content $(52-62 \mathrm{wt} \%)$. In contrast, $(\mathrm{Ce} / \mathrm{Yb})_{\mathrm{CN}}$ in the calc-alkaline suite show much greater variation (2.17 to 2.94) over a smaller range in $\mathrm{SiO}_{2}$ content ( 56 to $62 \mathrm{wt} \%$ ) and increase systematically with $\mathrm{SiO}_{2}$.

REE data for the tholeiitic suite are consistent with a crystal fractionation model that successfully reproduces the observed major- and trace-element variations. A similar fractionation model is compatible with major-element and some trace-element variations for the calc-alkaline suite, but results in excessively high heavy REE contents, and fails to reproduce the elevated $(\mathrm{Ce} / \mathrm{Yb})_{\mathrm{CN}}$ ratios for the most acidic samples. The preferential enrichment of light REEs may reflect additional processes such as: (1) assimilation, (2) incorporation of a differentiated liquid (or evolved magma) that has undergone fractionation of heavy REE-rich minerals, and (3) mixing of primary magma derived by a small degree of partial melting from a common (amphibolitic or hornblende gabbroic) source.

Although the tholeiitic and calc-alkaline suites possess distinct ${ }^{87} \mathrm{Sr} /{ }^{86} \mathrm{Sr}, \mathrm{Rb} / \mathrm{Ba}$ and $\mathrm{Zr} / \mathrm{Nb}$ ratios, different magma sources are not required to produce the distinct REE patterns of the coexisting suites. An equilibrium batch partial melting model can reproduce both the flat (tholeiitic) and concave (calcalkaline) REE patterns from a common peridotitic source by larger (10-15\%) and smaller (5\%) degrees of partial melting, respectively. Therefore, both tholeiitic and calc-alkaline suites could have been derived from a common lherzolitic magma source, provided that the calc-alkaline suite underwent incorporation (assimilation) of isotopically distinct (lower crust-derived) materials prior to evolution.
\end{abstract}

\section{INTRODUCTION}

Island-arc tholeiitic suites (Jakes and Gill, 1970) are closely associated with calc-alkaline suites in the outer volcanic zone of the Northeast Japan arc (Nasu volcanic zone; NVZ) (Kawano and Aoki, 1960, Kawano et al., 1961, Yoshida and Aoki, 1984). As reviewed by Fujinawa (1988), several petrologists have tried to determine the evolutionary processes for each magma suite and/or a possible genetic relationship between the suites. On the basis of trace-element compositions of tholeiitic and calc-alkaline lavas from the NVZ, Masuda and Aoki (1979) argued that these two magma suites could not have been derived from a common parental magma. They instead proposed that both tholeiitic and calcalkaline parental magmas were generated from the same peridotitic mantle through higher (about 20\%) and lower (about 3\%) degrees of partial melting. In contrast, based on petrography and mineralogy, Sakuyama (1981, 1983) and Wada $(1981,1985)$ cited magma mixing as an important process in the evolution of 
calc-alkaline magma suites.

Fujinawa (1988) investigated the major-element, trace-element and Sr-isotope geochemistry of lavas at Adatara volcano located in the NVZ, and concluded that: (1) members of the tholeiitic suite are related principally through fractional crystallization of the observed phenocryst phases; (2) a similar fractionation mechanism is dominant in the evolution of the calc-alkaline suite, with subordinate magma mixing as an additional mechanism; and (3) tholeiitic and calcalkaline lavas were probably derived from different parental magmas, with postulated calcalkaline parental magma having higher $\mathrm{Rb} / \mathrm{Ba}$, $\mathrm{Zr} / \mathrm{Nb}$ and lower ${ }^{87} \mathrm{Sr} /{ }^{86} \mathrm{Sr}$ ratios than tholeiitic parental magma. Mineralogical data for these samples (Fujinawa, 1990a) are compatible with these conclusions. It may be noteworthy that the fractionation-magma mixing model of Fujinawa (1988) is in accord with recent general discussions on the origin of calc-alkaline suites in island-arc regions (Luhr and Carmichael, 1980, 1985; Kosco, 1981; Grove et al., 1982, 1983; Kay et al., 1982; Grove and Baker, 1984). Recently, Fujinawa (1990b, 1991) argued that high $\mathrm{Rb} / \mathrm{Ba}$, $\mathrm{Zr} / \mathrm{Nb}$ and, possibly, low ${ }^{87} \mathrm{Sr} /{ }^{86} \mathrm{Sr}$ ratios in the calc-alkaline parental magma could well have been caused by anatexis of lower crust and subsequent incorporation (assimilation) of the anatectic melt into mantle derived basaltic magma, presuming that lower crust beneath the Northeast Japan arc has amphibolitic or hydrous gabbroic composition with ${ }^{87} \mathrm{Sr} /{ }^{86} \mathrm{Sr}$ as low as 0.7030 .

Previous work concerning the REE compositions of lavas from the NVZ is apparently not in agreement with the conclusions of Fujinawa (1988, 1990a). By averaging the available REE data of NVZ lavas, Masuda and Aoki (1979) demonstrated that: (1) flat REE patterns are common among the tholeiitic basalts; (2) calcalkaline andesites are characterized by light REE [LREE]-enriched concave patterns; and (3) the concave upward REE patterns for tholeiitic andesites are virtually indistinguishable from the patterns for calc-alkaline andesites. Unfortunately, Masuda and Aoki did not interpret these variaties (or variations) in detail. Fujimaki (1980) emphasized the similarlity in REE patterns among two tholeiitic samples and their intimately associated one calc-alkaline sample from Iwate volcano located in the northern region of the NVZ, and concluded that temporally and spatially associating tholeiitic and calcalkaline magmas could have been derived from a common parental magma.

The aim of this paper is to reevaluate, using previously published and new REE data, the magmatic evolution within both tholeiitic and calc-alkaline magma suites and the relationship between these suites. To achieve these goals, it is important to determine: (1) differences (or similarlities) in REE patterns between the two suites; and (2) parallelism of REE patterns [i.e. constant $(\mathrm{Ce} / \mathrm{Yb})_{\mathrm{CN}}$ ratios] among the members of each suite. Based on REE data, fractionation models were constructed to examine the role of crystal fractionation in the magmatic evolution of each rock suite. Also, equilibrium partial melting models were examined to test consanguinity between the two suites.

\section{SAMPle Descriptions}

The analyzed samples include 9 tholeiitic and 13 calc-alkaline lavas from Adatara volcano. Major- and trace-element compositions of these samples were presented in previous papers (Fujinawa, 1980, 1984, 1988) along with their petrography and modal compositions. A detailed description of the mineralogy of these samples is available in Fujinawa (1990a). Sample numbers are consistent with those used previously (Fujinawa, 1988, 1990a). Tholeiitic samples range from basalt $\left(\mathrm{SiO}_{2} ; 52 \mathrm{wt} \%\right)$ through andesite $\left(\mathrm{SiO}_{2} ; 53 \%-61.7 \%\right)$, and calc-alkaline samples from basic andesite $\left(\mathrm{SiO}_{2} ; 55.9 \%\right)$ to acidic andesite $\left(\mathrm{SiO}_{2} ; 61.7 \%\right)$. Tholeiitic samples commonly contain plagioclase as the most abundant phenocryst phase, followed by hypersthene, augite and titanomagnetite, in order of abundance. Olivine phenocrysts are found in the basic tholeiites, i.e. those containing $<55 \mathrm{wt} \% \mathrm{SiO}_{2}$. Calc-alkaline samples com- 
monly contain plagioclase $>$ hypersthene $>$ augite $>$ titanomagnetite as the dominant phenocryst phases. Rare phenocrysts of olivine, ilmenite and quartz occur in some of the calcalkaline samples. Quartz phenocrysts are partially resorbed.

\section{Analytical Procedure and Results}

REE contents were determined by inductively coupled argon plasma/optical emission spectroscopy (ICAP/OES) following the method of Tagiri and Fujinawa (1988) which is based on the technique of Crock and Lichte (1982). The ICAP emission spectrometer employed is a Jarrell-Ash Model 575 set up at Ibaraki University. Two or three replicate analyses were made of each sample (see Table 1 for results of replicate analyses).

Results of REE analyses together with $\mathrm{SiO}_{2}$ and $\mathrm{K}_{2} \mathrm{O}$ contents are listed in Table 2, and chondrite-normalized REE patterns for representative samples are presented in Figs. 1 and 2. Tholeiitic and calc-alkaline suite samples can be easily distinguished from each other on the basis of REE compositions. Tholeiitic samples commonly display nearly flat REE patterns, whereas calc-alkaline samples are characterized by LREE-enriched concave patterns.

In the tholeiitic suite, both LREE and heavy
REEs (HREE) vary sympathetically with $\mathrm{K}_{2} \mathrm{O}$ and other incompatible elements. As $\mathrm{SiO}_{2}$ increases from 52 to $62 \mathrm{wt} \%, \mathrm{Ce}$ and $\mathrm{Yb}$ abundances increase from 14 to $23 \mathrm{ppm}$ and from 2.15 to $3.3 \mathrm{ppm}$, respectively. However, relative to the increase in REE abundances, chondritenormalized $\mathrm{Ce} / \mathrm{Yb}$ ratios $\left[(\mathrm{Ce} / \mathrm{Yb})_{\mathrm{CN}}\right]$ increase only slightly, varying within a narrow range (1.54 and 1.80).

In the calc-alkaline suite, on the other hand, LREEs and, to a lesser extent, HREEs increase with increasing $\mathrm{SiO}_{2}$, whereas Eu remains almost constant, resulting in significant negative $\mathrm{Eu}$ anomalies in the most silicic lavas. As $\mathrm{SiO}_{2}$ increases from 56 to $62 \mathrm{wt} \%,(\mathrm{Ce} / \mathrm{Yb})_{\mathrm{CN}}$ ratios gradually increase from 2.17 to 2.94 .

\section{Discussion}

\section{Fractional crystallization models}

\section{(1) Tholeiitic suite}

A general consensus has emerged among petrologists favoring the generation of island arc tholeiitic suite lavas by fractional crystallization of basaltic parental magmas (Ewart et al. 1973; Brown et al. 1977; Togashi 1977; Depaolo and Johnson 1979; Masuda and Aoki 1979; Sakuyama 1981, 1983; Gill 1981; Sakuyama and Nesbitt 1986). Major- and trace-element variations for the tholeiitic suite at Adatara volcano

Table 1. Results of replicate ICP analyses for particular samples

\begin{tabular}{|c|c|c|c|c|c|c|c|c|c|c|}
\hline \multirow{2}{*}{ Spl. No. } & \multicolumn{5}{|c|}{$3-4$} & \multicolumn{5}{|c|}{$3-8$} \\
\hline & 1 & 2 & 3 & Ave. & STD & 1 & 2 & 3 & Ave. & STD \\
\hline $\mathrm{La}$ & 8.58 & 8.63 & 8.62 & 8.61 & 0.0216 & 9.46 & 10.00 & 9.58 & 9.68 & 0.2315 \\
\hline $\mathrm{Ce}$ & 22.40 & 21.90 & 22.64 & 22.31 & 0.3082 & 23.60 & 23.70 & 22.20 & 23.17 & 0.6847 \\
\hline $\mathrm{Nd}$ & 13.40 & 13.00 & 12.48 & 12.96 & 0.3766 & 13.20 & 12.90 & 12.12 & 12.74 & 0.4551 \\
\hline $\mathrm{Sm}$ & 3.97 & 3.85 & 3.91 & 3.91 & 0.0490 & 3.76 & 3.79 & 3.56 & 3.70 & 0.1020 \\
\hline $\mathrm{Eu}$ & 1.04 & 1.03 & 0.94 & 1.00 & 0.0450 & 0.95 & 0.99 & 0.89 & 0.94 & 0.0410 \\
\hline Gd & 4.07 & 4.00 & 4.13 & 4.07 & 0.0531 & 3.78 & 3.64 & 3.71 & 3.71 & 0.0571 \\
\hline Dy & 4.25 & 4.15 & 4.17 & 4.19 & 0.0432 & 4.21 & 4.21 & 3.89 & 4.10 & 0.1508 \\
\hline $\mathrm{Er}$ & - & 2.81 & 2.76 & 2.79 & 0.025 & - & 3.27 & 2.69 & 2.98 & 0.29 \\
\hline $\mathrm{Yb}$ & 2.50 & 2.53 & 2.61 & 2.55 & 0.0464 & 2.61 & 2.63 & 2.56 & 2.60 & 0.0294 \\
\hline $\mathbf{L u}$ & - & 0.42 & 0.38 & 0.40 & 0.02 & - & 0.42 & 0.39 & 0.41 & 0.015 \\
\hline$(\mathrm{Ce} / \mathrm{Yb})_{\mathrm{CN}}$ & 2.29 & 2.21 & 2.21 & 2.24 & 0.0377 & 2.31 & 2.30 & 2.21 & 2.27 & 0.0449 \\
\hline
\end{tabular}

Spl. No.; sample number. (Ce/ Yb) $)_{C N}$; chondrite-normalized Ce/ Yb ratios. Chondritic values from Masuda et al. (1973). $S T D ;$ standard deviation $(\sigma)$. 
Table 2. Wet chemically determined $\mathrm{SiO}_{2}$ and $\mathrm{K}_{2} \mathrm{O}$ contents (wt $\%$ ) and REEs analyses (ppm) of whole rock samples by ICAP/OES

\begin{tabular}{|c|c|c|c|c|c|c|c|c|c|c|c|}
\hline Spl. No. & $\begin{array}{l}2-1 \\
\text { TH }\end{array}$ & $\begin{array}{l}2-2 \\
\text { TH }\end{array}$ & $\begin{array}{l}2-3 \\
\text { TH }\end{array}$ & $\begin{array}{l}2-4 \\
\text { TH }\end{array}$ & $\begin{array}{l}2-5 \\
\text { TH }\end{array}$ & $\begin{array}{l}2-6 \\
\text { TH }\end{array}$ & $\begin{array}{l}2-7 \\
\text { TH }\end{array}$ & $\begin{array}{l}2-9 \\
\text { TH }\end{array}$ & $\begin{array}{c}2-10 \\
\text { TH }\end{array}$ & $\begin{array}{l}3-1 \\
\text { CA }\end{array}$ & $\begin{array}{l}3-2 \\
\mathrm{CA}\end{array}$ \\
\hline $\mathrm{SiO}_{2}$ & 51.99 & 53.14 & 53.94 & 54.23 & 54.52 & 54.62 & 56.60 & 56.85 & 61.74 & 55.92 & 57.12 \\
\hline $\mathrm{K}_{2} \mathrm{O}$ & 0.28 & 0.40 & 0.34 & 0.29 & 0.40 & 0.37 & 0.42 & 0.59 & 0.79 & 1.17 & 1.05 \\
\hline $\mathrm{La}$ & 5.52 & 7.31 & 5.59 & 5.72 & 5.10 & 6.09 & 6.90 & 7.46 & 9.28 & 7.66 & 8.73 \\
\hline $\mathrm{Ce}$ & 13.89 & 16.14 & 14.53 & 15.10 & 14.05 & 14.66 & 17.13 & 18.61 & 23.19 & 21.40 & 23.82 \\
\hline $\mathrm{Nd}$ & 10.32 & 12.79 & 10.53 & 10.95 & 9.89 & 11.99 & 12.03 & 13.35 & 15.32 & 12.04 & 13.68 \\
\hline $\mathrm{Sm}$ & 3.20 & 3.73 & 3.28 & 3.51 & 3.30 & 3.57 & 3.96 & 3.99 & 4.82 & 3.76 & 4.24 \\
\hline $\mathrm{Eu}$ & 1.02 & 1.16 & 1.00 & 1.12 & 0.99 & 1.15 & 1.13 & 1.12 & 1.35 & 0.93 & 1.12 \\
\hline Gd & 3.51 & 3.91 & 3.56 & 3.58 & 3.63 & 3.97 & 4.23 & 4.38 & 5.26 & 3.80 & 4.28 \\
\hline Dy & 3.73 & 4.30 & 3.94 & 3.92 & 3.89 & 4.30 & 4.66 & 4.63 & 5.79 & 4.19 & 4.48 \\
\hline $\mathrm{Er}$ & 2.37 & 2.75 & 2.47 & 2.67 & 2.49 & 2.82 & 3.19 & 3.01 & 3.63 & 2.75 & 3.02 \\
\hline $\mathrm{Yb}$ & 2.16 & 2.32 & 2.26 & 2.19 & 2.19 & 2.43 & 2.69 & 2.72 & 3.30 & 2.51 & 2.69 \\
\hline $\mathrm{Lu}$ & 0.28 & 0.29 & 0.28 & 0.29 & 0.29 & 0.29 & 0.36 & 0.34 & 0.42 & 0.35 & 0.41 \\
\hline$(\mathrm{Ce} / \mathrm{Yb})_{\mathrm{CN}}$ & 1.64 & 1.78 & 1.64 & 1.76 & 1.64 & 1.54 & 1.62 & 1.74 & 1.80 & 2.17 & 2.26 \\
\hline
\end{tabular}

Abbreviations are same as those in Table 1. TH; tholeiitic series. $\mathrm{CA}$; calc-alkaline series. Source of $\mathrm{SiO}_{2}$ and $\mathrm{K}_{2} \mathrm{O}$ data is Fujinawa (1988).

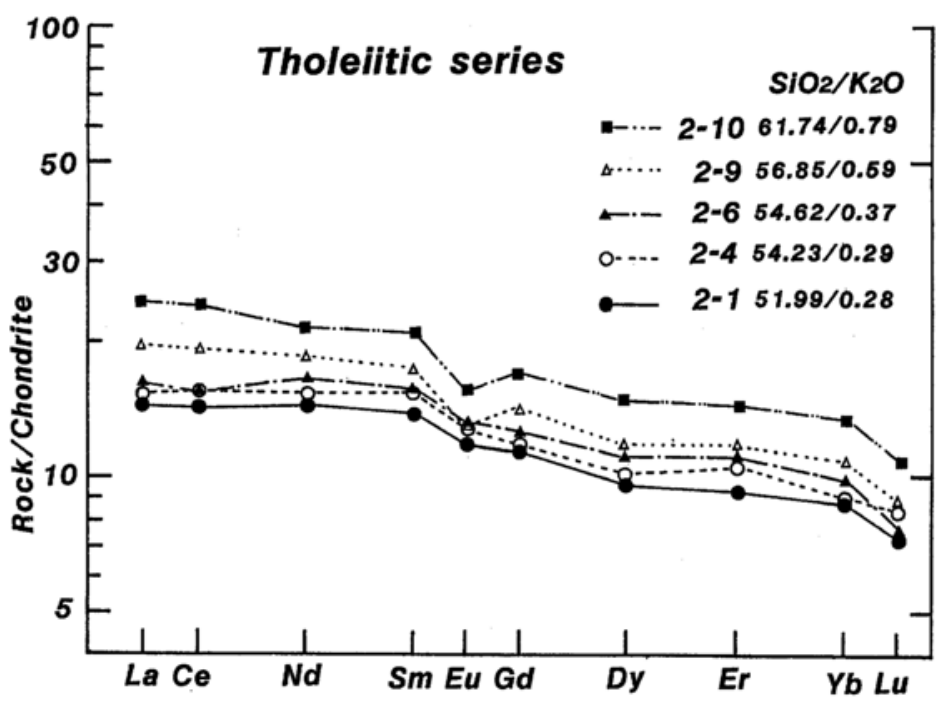

Fig. 1. Chondrite-normalized REE plot referenced to the Leedey chondrite (Masuda et al., 1973), showing the patterns for tholeiitic suite samples from Adatara volcano, Japan.

are also consistent with simple crystal fractionation of observed phenocryst assemblages, with 68-60 wt \% plagioclase, $21-25 \%$ hypersthene, 5$8 \%$ augite and $5-8 \%$ titanomagnetite \pm olivine as fractionated phases (Fujinawa, 1988). Such a model is supported by $\mathrm{Sr}$-isotopic data, in that ${ }^{87} \mathrm{Sr} /{ }^{86} \mathrm{Sr}$ ratios of the tholeiitic lavas lie within a limited range $0.7057 \pm 0.0001$ (Fujinawa, 1988).
Also, there are mineralogical observations concurring with the crystal fractionation hypothesis. These include: (1) complete absence of olivine in the tholeiitic lavas containing $>55 \% \mathrm{SiO}_{2} ;$ (2) positive correlations of $\mathrm{Fe} / \mathrm{Mg}$ ratios of mafic silicates and $\mathrm{Ca} / \mathrm{Na}$ of plagioclase with those of host lavas; and (3) increase in Usp $\mathrm{mol} \%$ of magnetite phenocryst cores with increasing 
Table 2. (continued)

\begin{tabular}{|c|c|c|c|c|c|c|c|c|c|c|c|}
\hline Spl. No. & $\begin{array}{l}3-3 \\
\mathrm{CA}\end{array}$ & $\begin{array}{l}3-4 \\
\text { CA }\end{array}$ & $\begin{array}{l}3-5 \\
\mathrm{CA}\end{array}$ & $\begin{array}{l}3-6 \\
\text { CA }\end{array}$ & $\begin{array}{l}3-8 \\
\mathrm{CA}\end{array}$ & $\begin{array}{l}3-9 \\
\text { CA }\end{array}$ & $\begin{array}{c}3-10 \\
\mathrm{CA}\end{array}$ & $\begin{array}{c}3-11 \\
\mathrm{CA}\end{array}$ & $\begin{array}{c}3-12 \\
\mathrm{CA}\end{array}$ & $\begin{array}{c}3-13 \\
\mathrm{CA}\end{array}$ & $\begin{array}{c}3-14 \\
\mathrm{CA}\end{array}$ \\
\hline $\mathrm{SiO}_{2}$ & 52.28 & 57.72 & 59.02 & 59.13 & 59.48 & 60.11 & 60.17 & 60.75 & 61.00 & 61.56 & 61.69 \\
\hline $\mathrm{K}_{2} \mathrm{O}$ & 1.24 & 1.14 & 1.16 & 1.63 & 1.53 & 1.58 & 1.47 & 1.71 & 1.37 & 1.68 & 1.98 \\
\hline La & 8.47 & 8.61 & 10.66 & 10.03 & 9.68 & 11.25 & 11.76 & 12.40 & 12.13 & 10.75 & 13.18 \\
\hline $\mathrm{Ce}$ & 22.47 & 22.31 & 25.80 & 25.61 & 23.17 & 27.85 & 28.50 & 30.07 & 30.34 & 26.48 & 32.28 \\
\hline $\mathrm{Nd}$ & 12.70 & 12.96 & 13.93 & 13.66 & 12.74 & 16.20 & 15.84 & 16.58 & 17.58 & 14.97 & 16.93 \\
\hline $\mathrm{Sm}$ & 3.77 & 3.91 & 4.11 & 3.93 & 3.70 & 4.79 & 4.53 & 4.35 & 4.79 & 4.15 & 4.74 \\
\hline Eu & 0.96 & 1.00 & 0.94 & 0.88 & 0.94 & 1.16 & 0.99 & 1.01 & 1.14 & 0.87 & 0.93 \\
\hline Gd & 3.89 & 4.07 & 4.11 & 3.82 & 3.71 & 4.70 & 4.37 & 4.28 & 4.81 & 4.07 & 4.38 \\
\hline Dy & 4.27 & 4.19 & 4.44 & 4.05 & 4.10 & 5.05 & 4.64 & 4.84 & 5.23 & 4.38 & 4.58 \\
\hline $\mathrm{Er}$ & 2.77 & 2.79 & 2.84 & 2.65 & 2.98 & 3.22 & 3.88 & 3.09 & 3.31 & 2.81 & 2.92 \\
\hline $\mathrm{Yb}$ & 2.65 & 2.55 & 2.82 & 2.43 & 2.60 & 3.09 & 2.78 & 2.95 & 3.14 & 2.72 & 2.80 \\
\hline Lu & 0.38 & 0.40 & 0.41 & 0.40 & 0.41 & 0.45 & 0.35 & 0.45 & 0.46 & 0.39 & 0.42 \\
\hline$(\mathrm{Ce} / \mathrm{Yb})_{\mathrm{CN}}$ & 2.16 & 2.24 & 2.33 & 2.68 & 2.27 & 2.30 & 2.61 & 2.60 & 2.47 & 2.48 & 2.94 \\
\hline
\end{tabular}

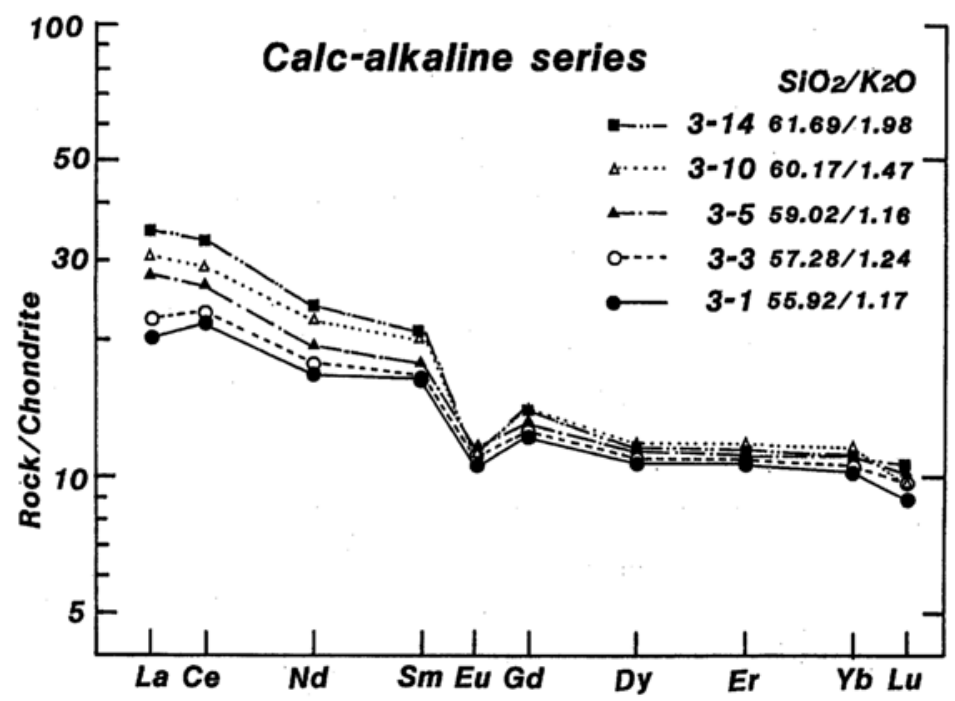

Fig. 2. Chondrite-normalized REE plot showing the patterns for selected calc-alkaline suite samples from Adatara volcano.

whole rock $\mathrm{SiO}_{2}$ (Fujinawa, 1990a). The nearly parallel REE patterns of the tholeitic samples provide further evidence that these lavas are related through crystal fractionation, because the content of augite, the only phase which would fractionate LREE and HREE in the fractionated phases, was estimated to be as low as 5$8 \mathrm{wt} \%$ (Table 3 ).

In order to test the fractionation hypothesis of Fujinawa (1988), REE variations in the tholeiitic suite were modelled assuming Rayleigh fractionation of observed phenocryst phases. The weight proportion of phases that must be removed from chosen parent magmas to derive daughter magmas is estimated by averaging successful results of least-squares calculations after the method of Wright and Doherty (1970) (Table 3; Ave. B and Ave. A). Mineral compositions 
Table 3. Results of least-squares calculation (after Wright and Doherty, 1970) and weight $\%$ of crystals in the fractionated phases

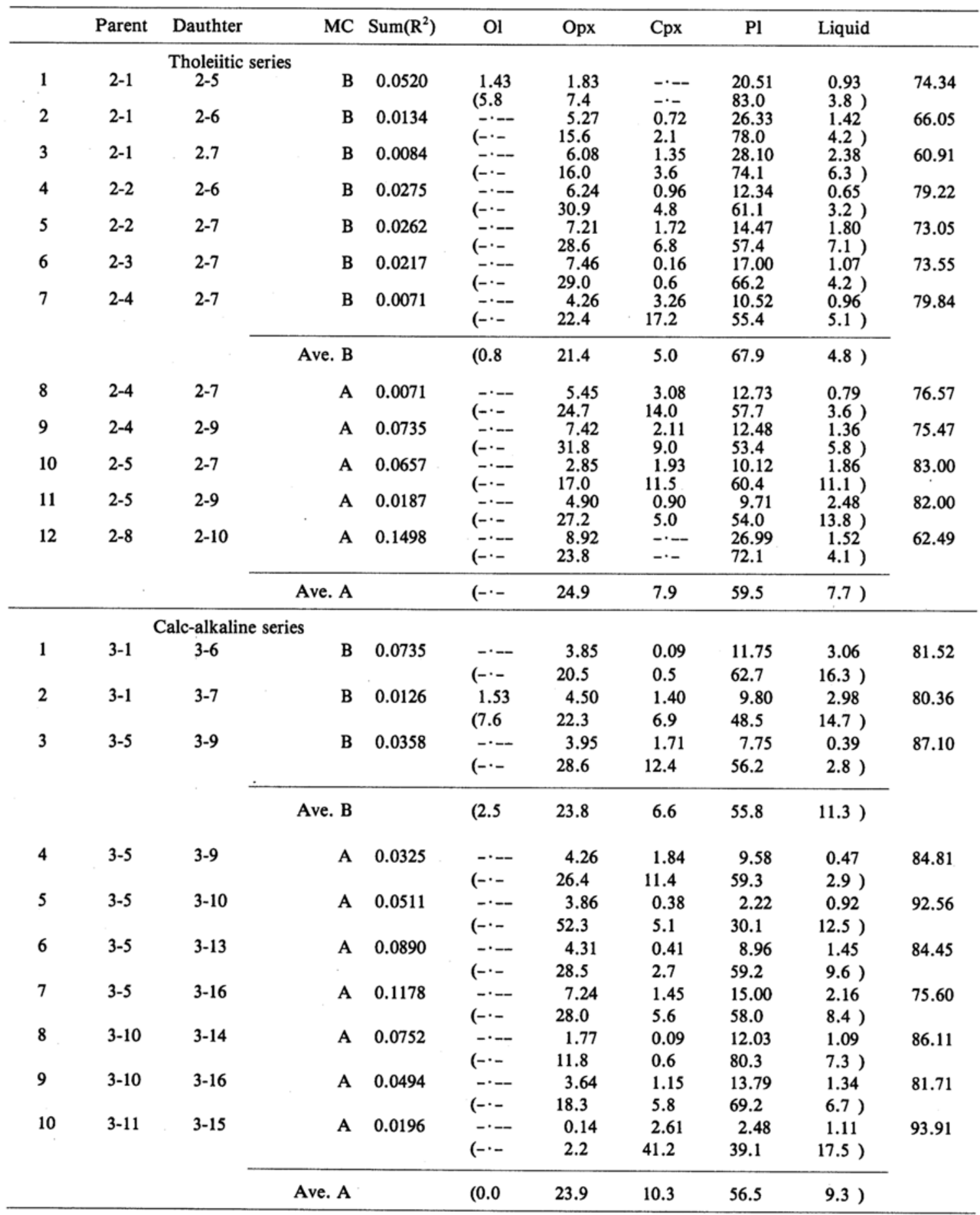

$B$ and $A$ at the column MC indicates the set of chemical compositions of basic and acidic fractionated phase assemblages, respectively. They are available in Table 6 of Fujinawa (1988). Values in parentheses represent weight $\%$ of the crystals in the fractionated phases. Sample Nos. correspond to those in Table 2. Data sources: Fujinawa (1988). 
Table 4. Estimates of $\mathrm{Ce}$ and $\mathrm{Yb}$ concentrations in residual magmas

\begin{tabular}{|c|c|c|c|c|c|c|c|c|c|c|c|}
\hline \multicolumn{12}{|c|}{ Tholeiitic series } \\
\hline $\begin{array}{l}\mathrm{SiO}_{2} \text { (residual magma) } \\
\mathrm{SiO}_{2} \text { (fractionated phases) }\end{array}$ & 52 & 53 & $\begin{array}{l}54 \\
47.0\end{array}$ & 55 & 56 & 57 & 58 & $\begin{array}{l}59 \\
47.2\end{array}$ & 60 & 61 & 62 \\
\hline DFTb & 1.000 & 0.833 & 0.714 & 0.625 & & & & & & & \\
\hline DFTa & & & & 1.000 & 0.886 & 0.796 & 0.722 & 0.661 & 0.609 & 0.565 & 0.527 \\
\hline \multirow[t]{2}{*}{$\mathrm{Ce}(\mathrm{MIN})(\mathrm{ppm})$} & 13.1 & 15.7 & 18.2 & 20.7 & & & & & & & \\
\hline & & & & 16.1 & 18.1 & 20.1 & 22.1 & 24.1 & 26.1 & 28.1 & 30.0 \\
\hline \multirow[t]{2}{*}{$\mathrm{Ce}(\mathrm{MAX})$} & 13.1 & 14.8 & 16.3 & 17.8 & & & & & & & \\
\hline & & & & 16.1 & 17.4 & 18.6 & 19.7 & 20.9 & 21.9 & 23.0 & 24.0 \\
\hline \multirow[t]{2}{*}{$\mathrm{Yb}(\mathrm{MIN})$} & 2.06 & 2.46 & 2.85 & 3.24 & & & & & & & \\
\hline & & & & 2.42 & 2.72 & 3.02 & 3.32 & 3.61 & 3.91 & 4.20 & 4.49 \\
\hline \multirow[t]{2}{*}{$\mathrm{Yb}$ (MAX) } & 2.06 & 2.27 & 2.46 & 2.64 & & & & & & & \\
\hline & & & & 2.43 & 2.57 & 2.70 & 2.82 & 2.94 & 3.05 & 3.16 & 3.26 \\
\hline \multirow{2}{*}{$(\mathrm{Ce} / \mathrm{Yb})_{\mathrm{CN}}(\mathrm{MIN})$} & 1.62 & 1.63 & 1.63 & 1.63 & & & & & & & \\
\hline & & & & 1.69 & 1.70 & 1.70 & 1.70 & 1.70 & 1.70 & 1.71 & 1.70 \\
\hline$(\mathrm{Ce} / \mathrm{Yb})_{\mathrm{CN}}(\mathrm{MAX})$ & 1.62 & 1.66 & 1.69 & 1.72 & 1.73 & 1.76 & & 181 & 183 & 186 & 1.88 \\
\hline \multicolumn{12}{|c|}{ Calc-alkaline series } \\
\hline \multirow{2}{*}{$\begin{array}{l}\mathrm{SrO}_{2} \text { (residual magma) } \\
\mathrm{SiO}_{2} \text { (fractionated phases) }\end{array}$} & 55.5 & 56 & 57 & 58 & 59 & 60 & 61 & 62 & 63 & & \\
\hline & & & 43.8 & & I & & 46.8 & & & & \\
\hline \multirow{2}{*}{$\begin{array}{l}\mathrm{DFCb} \\
\mathrm{DFCa}\end{array}$} & 1.000 & 0.959 & 0.886 & 0.824 & 0.770 & & & & & & \\
\hline & & & & & 1.000 & 0.924 & 0.859 & 0.803 & 0.753 & & \\
\hline \multirow[t]{2}{*}{$\mathrm{Ce}(\mathrm{MIN})(\mathrm{ppm})$} & 19.9 & 20.7 & 22.4 & 24.0 & 25.7 & & & & & & \\
\hline & & & & & 25.6 & 27.6 & 29.7 & 31.7 & 33.7 & & \\
\hline \multirow{2}{*}{$\mathrm{Ce}(\mathrm{MAX})$} & 19.9 & 20.4 & 21.4 & 22.4 & 23.4 & & & & & & \\
\hline & & & & & 25.6 & 26.9 & 28.1 & 29.3 & 30.4 & & \\
\hline \multirow[t]{2}{*}{$\mathrm{Yb}(\mathrm{MIN})$} & 2.48 & 2.58 & 2.78 & 2.98 & 3.18 & & & & & & \\
\hline & & & & & 2.73 & 2.94 & 3.16 & 3.37 & 3.58 & & \\
\hline \multirow[t]{2}{*}{$\mathrm{Yb}(\mathrm{MAX})$} & 2.48 & 2.53 & 2.62 & 2.71 & 2.80 & & & & & & \\
\hline & & & & & 2.73 & 2.82 & 2.91 & 3.00 & 3.08 & & \\
\hline \multirow[t]{2}{*}{$(\mathrm{Ce} / \mathrm{Yb})_{\mathrm{CN}}(\mathrm{MIN})$} & 2.05 & 2.05 & 2.06 & 2.05 & 2.06 & & & & & & \\
\hline & & & & & 2.39 & 2.40 & 2.40 & 2.40 & 2.40 & & \\
\hline \multirow{2}{*}{$(\mathrm{Ce} / \mathrm{Yb})_{\mathrm{CN}}(\mathrm{MAX})$} & 2.05 & 2.06 & 2.08 & 2.11 & 2.13 & & & & & & \\
\hline & & & & & 2.39 & 2.43 & 2.46 & 2.49 & 2.52 & & \\
\hline
\end{tabular}

Degrees of fractionation, DFTb, DFTa, DFCb, and DFCa, are estimated in terms of weight fractions of residual magmas relative to chosen parent magmas, $\mathrm{Tb}, \mathrm{Ta}, \mathrm{Cb}$, and $\mathrm{Ca}$, respectively. Data source of the degree of fractionation is Fujinawa (1988).

used are the average phenocryst core compositions listed in Table 5 of Fujinawa (1988). Thus, the values of weight proportion are identical to those used for examining trace-element variations by Fujinawa (1988). Degrees of fractionation are estimated in terms of weight fractions of residual magmas relative to chosen parent magmas, which is also the same as that employed to examine the trace-element variations (Table 4). These are calculated by an addition-subtraction method using $\mathrm{SiO}_{2}$ contents in both whole rock samples and fractionated phases (cf. Fujinawa, 1988). Tholeiitic basalt magma (LDM of Fujinawa, 1988) containing $52 \mathrm{wt} \% \quad \mathrm{SiO}_{2}$ and andesite magma with $55 \mathrm{wt} \% \mathrm{SiO}_{2}$ are chosen as the parents for basaltic to andesitic residual (daughter) magmas $<55 \mathrm{wt} \% \mathrm{SiO}_{2}$ and andesitic residual magmas $>55 \mathrm{wt} \% \mathrm{SiO}_{2}$, respectively, in that olivine phenocryst perfectly disappears in tholeiitic lavas containing $>55 \mathrm{wt} \% \mathrm{SiO}_{2}$. For the calculations, $\mathrm{Ce}$ and $\mathrm{Yb}$ were chosen to represent the LREEs and HREEs, respectively (Table 
4). $\mathrm{Ce}$ and $\mathrm{Yb}$ abundances for the 2 chosen parents are approximated on the basis of best fits through all the data plots on silica variation diagrams (Table 4). Crystal-liquid partition coefficients are from the literature (Table 5). Maximum and minimum trends in Fig. 3 are drawn assuming maximum and minimum values of $\mathrm{D}_{\mathrm{Ce}}, \mathrm{D}_{\mathrm{Yb}}$ (Table 5; column A), respectively.

Data plots of the tholeiitic lavas come very close to the estimated variation trends, especially, maximum trend lines (Fig. 3), indicating that the REE data also support the crystal fractionation hypothesis. Furthermore, it should be noted that the successful fractionation model requires the highest values for both $D_{\mathrm{Ce}}$ and $\mathrm{D}_{\mathrm{Yb}}$ quoted in Table 5. These partition coefficients (Ds) are considerably higher than the Ds used in fractionation modelling of other incompatible elements in the earlier paper (Fujinawa, 1988).

\section{(2) Calc-alkaline suite}

The role of crystal fractionation in the evolution of the calc-alkaline suite was examined with the same method used for modelling the tholeiitic suite. The least differentiated magma (LDM of Fujinawa, 1988) with 55.5 wt $\% \mathrm{SiO}_{2}$ and an arbitrarily chosen andesite magma containing $59 \mathrm{wt} \% \mathrm{SiO}_{2}$ are regarded as the parents for basic to intermediate residual (daughter) magmas $<59 \mathrm{wt} \% \quad \mathrm{SiO}_{2}$ and acidic residual magmas $>59 \mathrm{wt} \% \mathrm{SiO}_{2}$, respectively. $\mathrm{Ce}$ and $\mathrm{Yb}$ abundances employed for these parents are also approximated values based on the best fits on the silica variation diagrams. In spite of the general success in reproducing the major- and some trace-element variations (Fujinawa, 1988), fractionation models consistently failed to reproduce the low HREE contents and the relatively high $(\mathrm{Ce} / \mathrm{Yb})_{\mathrm{CN}}$ ratios observed for acidic members of the suite (Fig. 3). Predicted fractionated mineral assemblages containing $<12 \mathrm{wt} \%$ augite (Table 3) are not supported by the REE data, because augite is the only phase which can significantly fractionate $\mathrm{Ce} / \mathrm{Yb}$ ratios (Schnetzler and Philpotts, 1970; Henderson, 1984; Fujimaki et al., 1984). Thus, compositional variations in the calc-alkaline suite cannot be explained solely by crystal fractionation of observed phenocrystic phases.

A significant contribution by other process(es) is required to explain the observed enrichment of LREEs relative to HREEs. Several proc-

Table 5. Partition coefficients employed in fractionation model

\begin{tabular}{|c|c|c|c|c|c|c|}
\hline & \multicolumn{2}{|c|}{$\mathrm{Ce}$} & \multicolumn{2}{|c|}{$\mathrm{Eu}$} & \multicolumn{2}{|c|}{$\mathrm{Yb}$} \\
\hline & A & B & A & B & A & B \\
\hline olivine & $0.008-0.03$ & $\begin{array}{l}0 \\
(0-0.005)\end{array}$ & $0.005-0.05$ & $\begin{array}{l}0 \\
(0-0.005)\end{array}$ & $0.03-0.07$ & $\begin{array}{l}0 \\
(0-0.004)\end{array}$ \\
\hline $\begin{array}{l}\text { ortho- } \\
\text { pyroxene }\end{array}$ & $0.03-0.33$ & $\begin{array}{l}0.006 \\
(0.001-0.01)\end{array}$ & $0.03-0.42$ & $\begin{array}{l}0.02 \\
(0.0036-0.05)\end{array}$ & $0.1-0.67$ & $\begin{array}{l}0.08 \\
(0.029-0.2)\end{array}$ \\
\hline $\begin{array}{l}\text { clino- } \\
\text { pyroxene }\end{array}$ & $0.043-0.65$ & $\begin{array}{l}0.05 \\
(0.033-0.17)\end{array}$ & $0.09-2.0$ & $\begin{array}{l}0.48 \\
(0.14-0.75)\end{array}$ & $0.09-1.5$ & $\begin{array}{l}0.6 \\
(0.16-1.0)\end{array}$ \\
\hline plagioclase & $0.02-0.3$ & 0.12 & $\begin{array}{c}0.02-2.11 \\
0.02-0.4(\mathrm{TH}) \\
0.5-1.0(\mathrm{CA})\end{array}$ & 0.2 & $0.006-0.3$ & 0.067 \\
\hline magnetite & $0.06-0.82$ & & $0.06-0.66$ & & $0.09-1.0$ & \\
\hline spinel & & $\begin{array}{l}0.015 \\
(0-0.03)\end{array}$ & & $\begin{array}{l}0.025 \\
(0-0.05)\end{array}$ & & $\begin{array}{l}0.05 \\
(0-0.1)\end{array}$ \\
\hline
\end{tabular}

$A$ and B; partition coefficients for crystal/andesitic liquid and crystal/ basaltic liquid, respectively. TH; tholeiitic series, CA; calc-alkaline series. Values in parentheses are ranges of partition coefficients for crystal/ basaltic liquid. Data srouces: Onuma et al. (1968), Schnetzler and Phillpotts (1970), Bornhorst (1980), Nicholls and Harris (1980), Gill (1981), Villemant et al. (1981), Dostal et al. (1983), Fujimaki et al. (1984), Henderson (1984), and Luhr and Carmichael (1985) for A; Baxter et al. (1985), Feigenson et al. (1983), and Irving and Frey (1984) for B. 


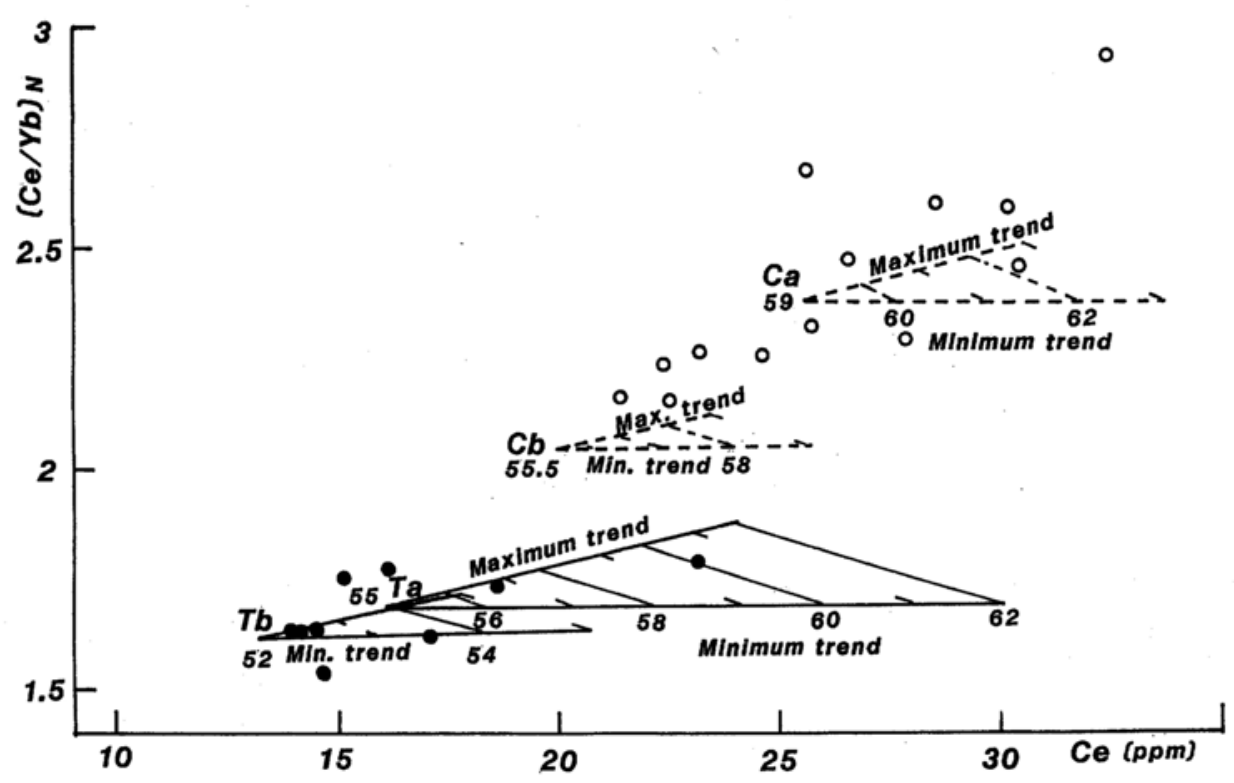

Fig. 3. $(\mathrm{Ce} / \mathrm{Yb})_{\mathrm{CN}}$ vs. Ce diagram showing plots of whole rock analyses and fractionation paths predicted on the basis of Rayleigh fractionation models. Solid circles=tholeitic samples, open circles=calc-alkaline samples. Solid and broken lines indicate the trend lines for the tholeiitic and calc-alkaline magma series, respectively. $\mathrm{Tb}, \mathrm{Ta}, \mathrm{Cb}$, and $\mathrm{Ca}$, are 4 chosen parent magmas: $\mathrm{Tb}$ and $\mathrm{Cb}$ refer to tholeiitic and calc-alkaline $L D M s$ of Fujinawa (1988), $\mathrm{Ta}=$ tholeiitic andesite containing $55 \mathrm{wt} \% \mathrm{SiO}_{2}$, and $\mathrm{Ca}=$ calc-alkaline andesite with 59 $w t \% \mathrm{SiO}_{2}$. Each fractionation trend is denotated according to $\mathrm{SiO}_{2}$ contents of the residual magmas.

esses could produce such an enrichment, including: (1) assimilation; (2) incorporation of liquid (or highly evolved magma) that has undergone fractionation of HREE-rich minerals into differentiating magma; and (3) mixing of small partial melts derived from a common source material. In each case, the two endmembers, i.e. host magma and assimilant or end-member magmas, need to possess similar ${ }^{87} \mathrm{Sr} /{ }^{86} \mathrm{Sr}, \mathrm{Rb} / \mathrm{Ba}$ and $\mathrm{Zr} / \mathrm{Nb}$ ratios, since these ratios remain almost constant through the suite.

Model (3) is not plausible without an assumption that lower crust-derived mafic materials such as amphibolite or hornblende gabbro are the principal source of calc-alkaline magmas (Takahashi and Tomiya, 1990), because simultaneous increase of both $(\mathrm{Ce} / \mathrm{Yb})_{\mathrm{CN}}$ and $\mathrm{Ce}$ with $\mathrm{SiO}_{2}$ would be brought about either by some fractionation mechanism or mixing of acidic component. Ultramafic source can not generate acidic (dacitic to rhyolitic) end-member magma by partial melting under probable melting conditions beneath NVZ.

The negative Eu anomalies observed for calcalkaline suite lavas likely reflect both the dominance of plagioclase in the fractionated phase assemblages (Table 3 ) and the high $\mathrm{D}_{\mathrm{Eu}}$ value for plagioclase. Petrographically observed apparent partition coefficients (separated plagioclase phenocryst/groundmass) for $\mathrm{Eu}$ range as high as 1.0 for calc-alkaline samples from the NVZ (Odaka, unpublished data). In contrast, the apparent $\mathrm{D}_{\mathrm{Eu}}$ values for plagioclase are consistently low $\left(\mathrm{D}_{\mathrm{Eu}}=0.2-0.4\right)$ for $\mathrm{NVZ}$ tholeiites. $D_{E u}$ is known to be dependent on the redox state of magmas; under extreme reducing conditions, the $\mathrm{D}_{\mathrm{Eu}}$ approaches a value similar to that of $\mathrm{D}_{\mathrm{Sr}}$ (Drake and Weill, 1975). However, the apparent $\mathrm{D}_{\mathrm{Eu}} \mathrm{S}$ are quite opposite to what is expected from the inferred $f \mathrm{O}_{2}$ conditions for the two magma series at Adatara volcano. Fujinawa (1990a) considered, on the bases of mineralogy and phase relations of phenocrystic oxides, that the tholeiitic magma evolved under 
lower $f \mathrm{O}_{2}$ and higher temperature $(100 \mathrm{C}$ difference) conditions than the calc-alkaline magma. The difference of apparent $\mathrm{D}_{\mathrm{Eu}} \mathrm{s}$ might reflect temperature dependence more than $\mathrm{fO}_{2}$ dependence, because a linear relationship between $\ln \mathrm{D}_{\mathrm{Eu}}$ and inverse temperature is experimentaly observed in oceanic ridge basalt (Sun et al., 1974).

\section{Batch partial melting model}

An equilibrium partial melting model was applied to test whether the distinct REE patterns of tholeiitic and calc-alkaline suite lavas could have been generated from a common magma source by different degrees of partial melting. Spinel lherzolite is employed as the source material, because low-alkali tholeiitic magmas in the NVZ are believed to segregate from underlying lherzolitic upper mantle at the pressure around 10 $\mathrm{kb}$, where spinel is thought to be the most probable stable aluminous phase (Tatsumi, 1986; Nakagawa et al., 1988). The modelling is based on the following assumptions: (1) the spinel lherzolite consists of $58 \%$ olivine, $25 \%$ orthopyroxene, $15 \%$ clinopyroxene and $2 \%$ spinel by weight, corresponding to the modal composition of KLB-1, the most undepleted spinel lherzolite xenolith from Kilborne Hole, New Mexico (cf. Takahashi, 1986a); (2) the lherzolite has a flat REE pattern, and contains tentatively the same REE abundances as the Leedey chondrite (Masuda et al., 1973); (3) REE partitioning between source material $\left(C_{O}\right)$ and partial melt $\left(C_{L}\right)$ is adequately described by the equation $C_{L} / C_{O}=1 /\left[D_{O}+F(1-P)\right]$, where $F$ is the degree of partial melting, and $\mathrm{D}_{\mathrm{o}}$ and is the bulk partition coefficients related to modal source composition, and $\mathrm{P}$ is modal melt composition (i.e. modal composition of minerals entering into melt), respectively (Shaw, 1970); and (4) the melting relations and ratio of the phases incorporated into the melt in each melting interval are those listed in Table 6.

Results indicate that varying degrees of partial melting of a common lherzolitic source can account for the distinct REE patterns displayed by tholeiitic and calc-alkaline suite lavas (Fig. 4). Less than $5 \%$ partial melting can generate concave REE patterns similar to those observed for calc-alkaline lavas, whereas greater than $10 \%$ partial melting can produce virtually flat REE patterns similar to those observed for tholeiitic lavas. These results coincide with the findings of Masuda and Aoki (1979).

The fact that the postulated parental magmas are lower in REE abundances than the most mafic lavas observed (eg. 2-1, 3-1) can well be explained by presuming a source with higher REE abundances and/or earlier (deep-level) olivinedominated fractionation of primary magmas. Indeed, several estimates of mantle compositions (Jagoutz et al., 1979; Hart and Zindler, 1986) have 1.5 to 2.5 times chondritic REE abundances. In view of the fact that $\mathrm{Mg}$ and $\mathrm{Ni}$ contents are consistently low in both rock suites, it is likely that even the most basic lavas underwent such fractionation before their eruption. Several petrologists have favored such a mechanism to explain the low $\mathrm{Mg}$ and $\mathrm{Ni}$ contents in basalts and andesites from the NVZ (Tatsumi et al.,

Table 6. Assumed melting relations among the phases in spinel lherzolite and the ratio of phases incorporated into the melt in the melting intervals from $0-5 \%, 5-25 \%$, and $>25 \%$

\begin{tabular}{|c|c|c|c|c|c|c|c|c|}
\hline \multirow{2}{*}{\multicolumn{2}{|c|}{$\begin{array}{l}\text { Degree of } \\
\text { partial melting }\end{array}$}} & \multicolumn{5}{|c|}{ Phase } & & \multirow[b]{2}{*}{ spinel } \\
\hline & & \multirow[t]{2}{*}{ olivine } & & \multicolumn{2}{|l|}{ orthopyroxene } & \multirow[t]{2}{*}{ clinopyroxene } & & \\
\hline & $0 \%$ & & & & & & & \\
\hline $0-5 \%$ & $\%$ & 1 & : & 1 & : & 4 & $:$ & 4 \\
\hline $5-25 \%$ & $25 \%$ & 1 & $:$ & $\begin{array}{c}1 \\
\text { clinopyroxene out }\end{array}$ & : & 4 & & \\
\hline$>25 \%$ & & 1 & $:$ & 1 & & & & \\
\hline
\end{tabular}




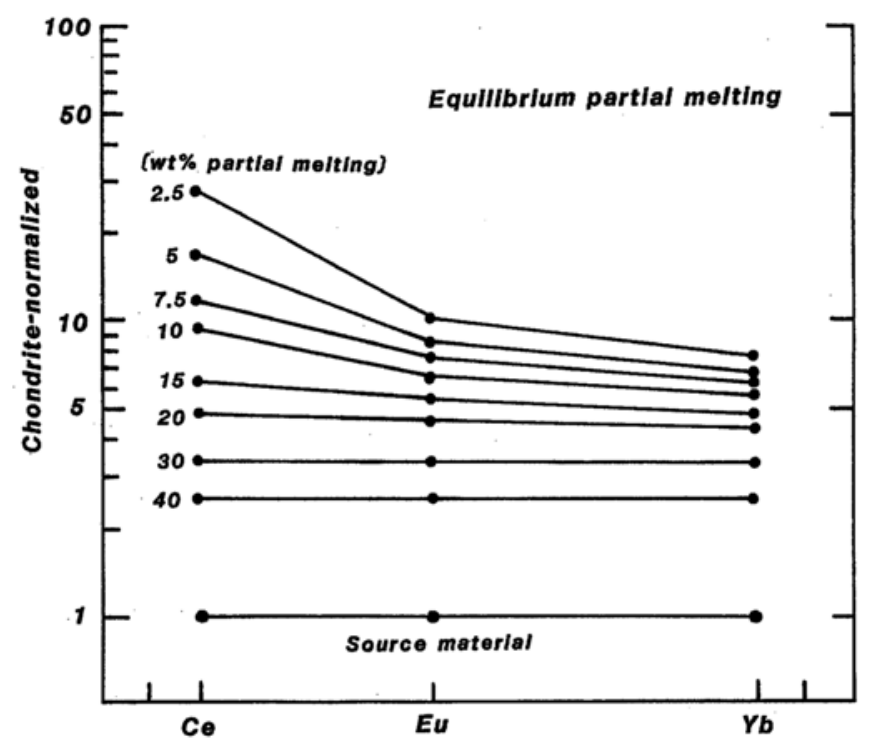

Fig. 4. Chondrite-normalized $\mathrm{Ce}, \mathrm{Eu}$ and $\mathrm{Yb}$ plot showing predicted $\mathrm{REE}$ patterns based on an equilibrium partial melting model. Chondritic values from Masuda et al. (1973).

1983; Yoshida and Aoki, 1988; Sakuyama and Nesbitt, 1986; Nakagawa et al., 1988; Fujinawa, 1988).

\section{Implications for magmagenesis}

Despite the REE evidence presented, distinct ${ }^{87} \mathrm{Sr} /{ }^{86} \mathrm{Sr}, \mathrm{Rb} / \mathrm{Ba}$ and $\mathrm{Nb} / \mathrm{Zr}$ ratios between tholeiitic and calc-alkaline lavas (Fujinawa, 1988) are apparently inconsistent with the view that the two parental magmas beneath Adatara volcano were directly produced from a common lherzolitic mantle source.

Fujinawa (1990b, 1991) proposed anatexis of lower crust and subsequent incorporation of the anatectic melt into an initial magma segregated from a mantle diapir as the most likely process to cause such high $\mathrm{Rb} / \mathrm{Ba}, \mathrm{Zr} / \mathrm{Nb}$ and, possively, low ${ }^{87} \mathrm{Sr} /{ }^{86} \mathrm{Sr}$ values in postulated calcalkaline parental magma. The proposal is based on an anatexis model assuming: (1) lower crust beneath Northeast Japan possesses amphibolitic or hydrous gabbroic composition (Kuno and Aoki, 1970; Aoki, 1971, 1973; Takahashi, 1978; Arai and Saeki, 1980; Tanaka and Aoki, 1980), with its ${ }^{87} \mathrm{Sr} /{ }^{86} \mathrm{Sr}$ as low as 0.7030 (Zashu et al., 1980 ); and (2) hydrous mafic rocks in the lowermost crust are fairly close to their melting tem- peratures (Takahashi, 1986b).

Provided that the REE concentrations in the magmas are buffered by dominant component, whereas ${ }^{87} \mathrm{Sr} /{ }^{86} \mathrm{Sr}, \mathrm{Rb} / \mathrm{Ba}$ and $\mathrm{Zr} / \mathrm{Nb}$ are sensitive to minor component, the tholeiitic and calc-alkaline suites could very well have been derived from a common source, with the calcalkaline suite undergoing assimilation of isotopically distinct materials during ascent to the magma chamber in which the magma evolved. The same magma-generation model would be plausible in case the isotopically distinct magma sources contain similar REE concentrations.

A similar contrastive nature of the tholeiitic and calc-alkaline magmas is commonly recognized among the volcanoes of NVZ, and this model implies that chemical characteristics of both primary basalt and anatectic melt should be approximately constant in the generation of calcalkaline parental magmas beneath the NVZ. Moreover, the roughly bimodal nature of these magma series in NVZ suggests that mixing proportion of the primary basalt and the anatectic melt should be approximately constant.

A possible explanation of such constancy is that amphibolitic or hornblende-gabbroic lower 
crust, as well as its underlain lherzolitic upper mantle, has analogous melting behavior to some multidimensional synthetic batch melting system. Namely, on a temperature vs. melting degree diagram its melting curve displays a segmented nature, with eutectic-like partial melt durng an initial stage of melting, and phases that disapper sequentially at greater degrees of partial melting, causing inflections in the melting curve. Under a similar tectonic, geochemical and geothermal environment such as the NVZ, the individual uprise of mantle diapir may cause a similar mannar of partial melting and anatexis underneath the volcanic centers, resulting in the crudely constant proportion of mantle-derived melt and lower crust-derived anatectic melt mentioned above.

An alternative model concordant with these geochemical data is that the tholeiites were derived from relatively shallow lithospheric mantle, whereas the calc-alkaline parental magmas were derived from the mantle wedge beneath the lithosphere, with the addition of a subducting “crustal" component contributed by melts from underlying oceanic slab. However, this model seems inconsistent with the $\mathrm{Sr}$ isotopic data of Adatara volcano, in that such a subducting component would be highly enriched in radiogenic $\mathrm{Sr}$.

A possible scenario that comprehensively explains the distinct geochemical characteristics of the tholeiitic and calc-alkaline parental magmas is as follows:

(1) Lherzolitic diapir, a possible common magma source, may have suffered enrichment of radiogenic $\mathrm{Sr}\left({ }^{87} \mathrm{Sr} /{ }^{86} \mathrm{Sr}\right.$ around 0.7056$)$ near the bottom of wedge mantle beneath Adatara volcano.

(2) The diapir rises within the upper mantle and begins to melt.

(3) Tholeiitic parental magma is produced by relatively high degree partial melting, segregating from the diapir under $10 \mathrm{~kb}$ pressure.

(4) When the partially molten lherzolitic diapir rises without segregating partial melt because of smaller degree of partial fusion, the diapir comes up to crust-mantle boundary, and stops rising by a balance of buoyancy. Emplacement of the hot diapir causes anatexis of lower crust. Eventually, the melt is squeezed out of the diapir, penetrates into the lower crust and incorporates liquid of anatexis origin, which gives rise to calc-alkaline parental magma.

\section{SUMMARY}

Flat REE patterns are common among the tholeiitic lavas of Adatara volcano, whereas associated calc-alklaine lavas are characterized by LREE-enriched, concave REE patterns. $(\mathrm{Ce} / \mathrm{Yb})_{\mathrm{CN}}$ ratios remain almost constant through the tholeiitic suite, whereas in the calcalkaline suite, $(\mathrm{Ce} / \mathrm{Yb})_{\mathrm{CN}}$ ratios increase systematically with increasing $\mathrm{SiO}_{2}$.

REE, major- and trace-element variations for the tholeiitic suite support the argument that these lavas are related principally by fractional crystallization of the observed phenocryst phases. Fractionation models are successful in reproducing the major- and some trace-element variations for the calc-alkaline suite, but fail to adequately predict $\mathrm{HREE}$ contents or $(\mathrm{Ce} / \mathrm{Yb})_{\mathrm{CN}}$ ratios for the most acidic lavas. The observed LREE enrichment may be the result of crystal fractionation combined with (1) assimilation, (2) incorporation of liquid (or residual magma) that has undergone fractionation of HREE-enriched minerals into differentiation magma, or (3) mixing of small partial melts originated from a common (amphibolitic or hb-gabbroic) source.

In view of the distinct ${ }^{87} \mathrm{Sr} /{ }^{86} \mathrm{Sr}, \mathrm{Rb} / \mathrm{Ba}$ and $\mathrm{Nb} / \mathrm{Zr}$ ratios between the two suites, tholeiitic and calc-alkaline magmas must be derived from different magma sources. However, the relevant magma sources do not necessarily possess distinct REE compositions. Equilibrium batch partial melting can successfully produce both the lavas with flat and lavas with concave REE patterns from a common lherzolitic source by different degrees of partial melting. A possible model of magma generation is that both tholeiitic and calc-alkaline magma suites are originated from a common lherzolitic diapir, 
with calc-alkaline suite undergoing incorporation of partial melt produced by anatexis of lower crust prior to evolution.

Acknowledgments-The late Prof. Naoki Onuma of Ibaraki Univ. kindly introduced the ICP facilities into our laboratory. Prof. M. Tagiri of Ibaraki Univ. continuously supported this study. Miss A. Odaka of Ibaraki Univ. kindly offered her unpublished data. Dr. H. B. West of University of Hawaii at Manoa critically read the manuscript and helpfully advised. The author is greatly indebted to them for their kind cooperation, constructive criticism and improvement of the manuscript. This work was supported by a Grant-in-Aid for Scientific Reserch (Nos. 63540643, 02640620) from the Ministry of Education, Science and Culture of Japan.

\section{REFERENCES}

Aoki, K. (1971) Petrology of mafic inclusions from Itinome-gata, Japan. Contrib. Mineral. Petrol. 30, 314-331.

Aoki, K. (1973) Ejected accidental fragments of Itinome-gata volcano-materials derived from upper mantle and lower crust. Mineral. J. 11, 100-111 (Japanese).

Arai, S. and Saeki, Y (1980) Ultramafic inclusions from Sannomegata crater, Oga peninsula, Japan, with special reference to the petrographical difference from the Ichinomegata inclusions. $J$. Geol. Soc. Japan 86, 705-708.

Baxter, A. N., Upton, B. G. J., and White, W. M. (1985) Petrology and geochemistry of Rodrigues Island, Indian Ocean. Contrib. Mineral. Petrol. 89, 90-101.

Bornhorst, T. J. (1980) Major- and trace-element geochemistry and mineralogy of upper Eocene to Quaternary rocks of the Mogollon-Datil volcanic field, southern New Mexico. Ph. D. dissertation, Univ. of New Mexico, Albuquerque, N.M.

Brown, G. M., Holland, J. G., Sigurdsson, H., Tomblin, J. F. and Arculus, R. J. (1977) Geochemistry of the Lesser Antilles volcanic island arc. Geochim. Cosmochim. Acta 41, 785-801.

Crock, J. G. and Lichte, F. E. (1982) Determination of rare earth elements in geological materials by inductively coupled argon plasma/atomic emission spectrometry. Anal. Chem. 54, 1329-1332.

DePaolo, D. J. and Johnson, R. W. (1979) Magma genesis in the New Britain island-arc: Constraints from $\mathrm{Nd}$ and $\mathrm{Sr}$ isotopes and trace-element patterns. Contrib. Mineral. Petrol. 70, 367-379.

Dostal, J., Dupuy, C., Carron, J. P., Kernrizon, M.
L-G, and Maury, R. C. (1983) Partition coefficients of trace elements: application to volcanic rocks of St. Vincent, West Indies. Geochim. Cosmochim. Acta, 47, 525-533.

Drake, M. J. and Weill, D. F. (1975) Partition of Sr, $\mathrm{Ba}, \mathrm{Ca}, \mathrm{Y}, \mathrm{Eu}^{2+}, \mathrm{Eu}^{3+}$, and other REE between plagioclase feldspar and magmatic liquid: an experimental study. Geochim. Cosmochim. Acta, 39, 669-712.

Ewart, A., Bryan, W. B., and, Gill, J. B. (1973) Mineralogy and Geochemistry of the younger volcanic island of Tonga, S. W. Pacific. J. Petrol. 14, 429-465.

Feigenson, M. D., Hoffmamm, A. W., and Spera, F. J. (1983) Case studies on the origin of basalt II. The transition from tholeiitic to alkalic volcanism on Kohala volcano, Hawaii. Contrib. Mineral. Petrol. 84, 390-405.

Fujimaki, H. (1980) Rare earth patterns for tholeiitic andesite and its associated calc-alkline andesite. $J$. Japan. Assoc. Min. Pet. Econ. Geol. 76, 93-101.

Fujimaki, H., Tatsumoto, M. and Aoki, K. (1984) Partition coefficients of $\mathrm{Hf}, \mathrm{Zr}$, and REE between phenocrysts and groundmasses. J. Geophys. Res. 89, B662-B672.

Fujinawa, A. (1980) Geology and petrology of Adatara volcano. J. Japan. Assoc. Min. Pet. Econ. Geol. 75, 385-395 (in Japanese with English abstract).

Fujinawa, A. (1984) Petrology and geochemistry of the Adatara volcano, Northeast Japan. Ph. D. dissertation, Tohoku Univ. 152pp.

Fujinawa, A. (1988) Tholeiitic and calc-alkaline magma series at Adatara volcano, Northeast Japan: 1. Geochemical constraints on their origin. Lithos 22, 135-158.

Fujinawa, A. (1990a) Tholeiitic and calc-alkaline magma series at Adatara volcano, Northeast Japan: 2. Mineralogy and phase relations. Lithos 24, 217236.

Fujinawa, A. (1990b) Tholeiitic and calc-alkaline magma series at Adatara volcano, Northeast Japan: Mechanism of evolution and petrological relationship. EOS 72, 967.

Fujinawa, A. (1991) Tholeiific and calc-alkaline magma series at Adatara volcano, Northeast Japan: Evolution mechanisms and genetic relationship. Bull. Volcanol. Soc. Japan 36 (241-254) (in Japanese with English abstract).

Gill, J. B. (1981) Orogenic andesites and plate tectonics. 390pp. Berlin. Heidelberg. New York: Springer-Verlag.

Grove, T. L. and Baker, M. B. (1984) Phase equilibrium controls on the tholeiitic versus calcalkaline differentiation trends. J. Geophys. Res. 89, 
3253-3274.

Grove, T. L., Gerlach, D. C. and Sando, T. W. (1982) Origin of calc-alkaline series lavas at Medicine Lake volcano by fractionation, assimilation and mixing. Contrib. Mineral. Petrol. 80, 160-182.

Grove, T. L., Gerlach, D. C., Sando, T. W. and Baker, M. B. (1983) Origin of calc-alkaline series lavas at Medicine Lake volcano by fractionation, assimilation and mixing: corrections and clarification. Contrib. Mineral. Petrol. 82, 407-408.

Hart and Zindler (1986) In search of a bulk-earth composition. Chem. Geol. 57, 247-267.

Henderson, P. (1984) Rare earth element geochemistry. 510pp. Amsterdam: Elsevier.

Irving, A. J. and Frey, F. A. (1984) Trace element abundances in megacrysts and their host basalts: Constraints on partition coefficients and megacryst genesis. Geochim. Cosmochim. Acta 48, 12011222.

Jagoutz, E., Palme, H., Baddenhausen, H., Blum, K., Cendales, M., Dreibus, G., Spettel, B., Lorenz, V. and Waenke, H. (1979) The abundances of major, minor and trace elements in the earth's mantle as derived from primitive ultramafic nodules. Proc. Lunar Planet. Sci. Conf. 10th, 2031-2050.

Jakes, P. and Gill, J. B. (1970) Rare earth elements and the island arc tholeiitic series. Earth Planet. Sci. Lett. 9, 17-28.

Kawano, Y. and Aoki, K. (1960) Petrology of Hachimantai and surrounding volcanoes, northeastern Japan. Sci. Rep. Tohoku Univ. Ser. 3 6, 409-449.

Kawano, Y., Yagi, K. and Aoki, K. (1961) Petrography and petrochemistry of the volcanic rocks of Quaternary volcanoes of northeastern Japan. Sci. Rep. Tohoku Univ., Ser. 3 7, 1-46.

Kay, S. M., Kay, R. W. and Citron, G. P. (1982) Tectonic controls on tholeiitic and calc-alkaline magmatism in the Aleutian arc. J. Geophys. Res. 87, 4051-4072.

Kosco, D. G. (1981) The Mt. Edgecumbe volcanic field, Alaska: An example of tholeiitic and calcalkaline volcanism. J. Geol. 89, 459-477.

Kuno, H. and Aoki, K. (1970) Chemistry of ultramafic nodules and their bearing on the origin of basaltic magmas. Phys. Earth Planet. Interiors 3, 273-301.

Luhr, J. F. and Carmichael, S. E. (1980) The Colima volcanic complex, Mexico. 1. Post-caldera andesites from Volcan Colima. Contrib. Mineral. Petrol. 71, 343-372.

Luhr, J. F. and Carmichael, S. E. (1985) Jorullo Volcano, Michoacan, Mexico (1759-1774): The earliest stages of fractionation in calc-alkaline magmas. Contrib. Mineral. Petrol. 90, 142-161.
Masuda, A., Nakamura, N. and Tanaka, T. (1973) Fine structures of mutually normalized rare-earth patterns of chondrites. Geochim. Cosmochim. Acta 37, 239-248.

Masuda, Y. and Aoki, K, (1979) Trace element variations in the volcanic-rocks from the Nasu zone, Northeast Japan. Earth Planet. Sci. Lett. 44, 139-149.

Nakagawa, M., Shimotori, H. and Yoshida, T. (1988) Across-arc compositional variation of the Quaternary basaltic rocks from the Northeast Japan arc. J. Min. Pet. Econ. Geol. 83, 9-25 (in Japanese with English abstract).

Nicholls, I. A. and Harris, K. L. (1980) Experimental rare earth element partition coefficients for garnet, clinopyroxene and amphibole coexisting with andesitic and basaltic liquids. Geochim. Cosmochim. Acta 44, 287-308.

Onuma, N., Higuchi, H., Wakita, H. and Nagasawa, H. (1968) Trace element partition between two pyroxenes and the host lava. Earth Planet. Sci. Lett. 5, 47-51.

Sakuyama, M. (1981) Petrological study of the Myoko and Kurohime volcanoes, Japan: crystallization sequence and evidence for magma mixing. $J$. Petrol. 22, 553-583.

Sakuyama, M. (1983) Petrology of arc volcanic rocks and their origin by mantle diapir. J. Volcanol. Geotherm. Res. 18, 297-320.

Sakuyama, M. and Nesbitt, R. W. (1986) Geochemistry of the Quaternary volcanic rocks of the Northeast Japan arc. J. Volcanol. Geotherm. Res. 29, 413-450.

Schnetzler, C. C. and Phillpotts, J. A. (1970) Partition coefficients of rare-earth elements between igneous matrix material and rock-forming mineral phenocrysts-II. Geochim. Cosmochim. Acta 34, 331-340.

Shaw, D. M. (1970) Trace element fractionation during anatexis. Geochim. Cosmochim. Acta 34, 237243.

Sun, C.-O., Williams, R. J. and Sun, S. S. (1974) Distribution coefficients of $\mathrm{Eu}$ and $\mathrm{Sr}$ for plagioclase-liquid and clinopyroxene-liquid equilibria in oceanic ridge basalt: an experimental study. Geochim. Cosmochim. Acta 28, 1415-1433.

Tagiri, M. and Fujinawa, A. (1988) Chemical analysis of REE and trace metals in GSJ rock reference samples by ICP. J. Min. Pet. Econ. Geol. 83, 102106 (in Japanese with English abstract).

Takahashi, E. (1978) Petrologic model of the crust and upper mantle of the Japanese island arcs. Bull. Volcanol. 41, 529-547.

Takahashi, E. (1986a) Melting of a dry peridotite KLB-1 up to $14 \mathrm{GPa}$ : Implications on the origin of peridotitic upper mantle. J. Geophys. Res. 91, 
9367-9382.

Takahashi, E. (1986b) Genesis of calc-alkali andesite magma in a hydrous mantle-crust boundary: Petrology of lherzolite xenoliths from the Ichinomegata crater, Oga penensula, northeast Japan, Part II. J. Volcanol. Ceotherm. Res. 29, 355-395.

Takahashi, E. and Tomiya, A. (1990) A model for deep magmatic processes beneath island arc volcano: Experimental and numerical constraints. EOS 71, 948.

Tanaka, T. and Aoki, K. (1980) Petrologic implications of REE and $\mathrm{Ba}$ data on mafic and ultramafic inclusions from Itinomegata, Japan. J. Geol. 89, 369-390.

Tatsumi, Y. (1986) Formation of the volcanic front in subduction zones. Geophys. Res. Lett. 13, 717-720.

Tatsumi, Y., Sakuyama, M., Fukuyama, H., and Kushiro, I. (1983) Generation of basaltic magmas and thermal structure of the mantle wedge in subduction zone. J. Geophys. Res. 88, 5815-5825.

Togashi, S. (1977) Petrology of Osoreyama volcano, Japan. J. Japan. Assoc. Min. Pet. Econ. Ceol. 72, 45-60 (in Japanese with English abstract).

Villemant, B., Jaffrezic, H., Joron, J-L., and Treuil, M. (1981) Distribution coefficients of major and trace elements; fractional crystallization in the alkali basalt series of Chaine des Puys (Massif Central, France). Geochim. Cosmochim. Acta 45, 1997-2016.

Wada, K. (1981) Contrasted petrological relations between tholeiitic and calc-alkalic series from Funagata volcano, northeast Japan. J. Jap. Assoc. Min. Pet. Econ. Geol. 76, 215-232.

Wada, K. (1985) Magma mixing process of calcalkalic andesites from Funagata volcano. J. Jap. Assoc. Min. Pet. Econ. Geol. 80, 467-483.

Wright, T. L. and Doherty, P. C. (1970) A linear programming and least squares computer method for solving petrologic mixing problems. Geol. Soc. Am. Bull. 81, 1995-2008.

Yoshida, T. and Aoki, K. (1984) Geochemistry of major and trace elements in the Quaterpary volcanic rocks from Northeast Honshu, Japan. Sci. Rep. Tohoku Univ. Ser. 3 16, 1-34.

Yoshida, T. and Aoki, K. (1988) Application of process identification method to the Quaternary volcanic rocks from Northeast Japan. Res. Rep. Lab. Nucl. Sci. Tohoku Univ. 21, 301-318 (Japanese).

Zashu, S., Kaneoka, I. and Aoki, K. (1980) Sr isotope study of mafic and ultramafic inclusions from Itinome-gata, Japan. Geochem. J. 14, 123-128. 